\title{
Alterations in Endothelin Receptors Following Hemorrhage and Resuscitation by Centhaquin
}

\author{
S. BRIYAL ${ }^{1}$, R. GANDHAKWALA ${ }^{1}$, M. KHAN ${ }^{1}$, M. S. LAVHALE ${ }^{2}$, A. GULATI ${ }^{1}$ \\ ${ }^{1}$ Department of Pharmaceutical Sciences, Midwestern University Chicago College of Pharmacy, \\ Downers Grove, IL, USA, ${ }^{2}$ Pharmazz Research Center, Pharmazz India Private Limited, Greater \\ Noida, UP, India
}

Received January 6, 2018

Accepted April 25, 2018

\section{Summary}

Endothelin-1 (ET-1) acts on $\mathrm{ET}_{\mathrm{A}}$ and $\mathrm{ET}_{\mathrm{B}}$ receptors and has been implicated in hemorrhagic shock (shock). We determined effect of shock and resuscitation by hypertonic saline (saline) or centhaquin on $\mathrm{ET}_{\mathrm{A}}$ and $\mathrm{ET}_{\mathrm{B}}$ receptor expression. Rats were anesthetized, a pressure catheter was placed in the left femoral artery; blood was withdrawn from the right femoral artery to bring mean arterial pressure (MAP) to $35 \mathrm{~mm} \mathrm{Hg}$ for $30 \mathrm{~min}$, resuscitation was performed and $90 \mathrm{~min}$ later sacrificed to collect samples for biochemical estimations. Resuscitation with centhaquin decreased blood lactate and increased MAP. Protein levels of $\mathrm{ET}_{\mathrm{A}}$ or $\mathrm{ET}_{\mathrm{B}}$ receptor were unaltered in the brain, heart, lung and liver following shock or resuscitation. In the abdominal aorta, shock produced an increase (140\%) in $\mathrm{ET}_{\mathrm{A}}$ expression which was attenuated by saline and centhaquin; $\mathrm{ET}_{\mathrm{B}}$ expression was unaltered following shock but was increased $(79 \%)$ by centhaquin. In renal medulla, $\mathrm{ET}_{\mathrm{A}}$ expression was unaltered following shock, but was decreased $(-61 \%)$ by centhaquin; shock produced a decrease $(-34 \%)$ in $\mathrm{ET}_{\mathrm{B}}$ expression which was completely attenuated by centhaquin and not saline. Shock induced changes in $\mathrm{ET}_{\mathrm{A}}$ and $\mathrm{ET}_{\mathrm{B}}$ receptors in the aorta and renal medulla are reversed by centhaquin and may be contributing to its efficacy.

\section{Key words}

Hemorrhagic shock • Centhaquin • Resuscitation • Endothelin • Cytokines

\section{Corresponding author}

A. Gulati, Chicago College of Pharmacy, Midwestern University, 555 31st Street, Downers Grove, IL 60515, USA. Fax: 630-9716097. E-mail: AGULAT@midwestern.edu

\section{Introduction}

Hemorrhagic shock often leads to multiple organ failure due to inadequate blood circulation, perfusion and oxygenation as a result of rapid and excessive blood loss (Wu et al. 2009). Multiple compensatory mechanisms to preserve oxygenation and tissue blood flow are initiated with the onset of hemorrhage. Despite resuscitation with intravenous fluids to restore circulation and oxygen delivery, patients may still undergo irreversible loss of blood perfusion, coagulopathy, hypothermia, acidosis, immune suppression, systemic inflammation, oxidative stress, multiple organ failure, and death (Acosta et al. 1998, Jacob and Kumar 2014). Deaths from hemorrhagic shock typically occur very early, mostly within the first $6 \mathrm{~h}$ of admission (Shackford et al. 1993).

We established that low doses of centhaquin (2-[2-(4-(3-methyphenyl)-1-piperazinyl)]ethyl-quinoline) citrate, significantly decreased blood lactate, and increased mean arterial pressure (MAP), pulse pressure (PP) and cardiac output (CO) in hemorrhagic shock (Gulati et al. 2012, Gulati et al. 2013, Lavhale et al. 2013, Papapanagiotou et al. 2016). We further carried out comparative studies between centhaquin and status quo resuscitative agents grouped into 3 different categories: a) fluids such as Lactated Ringer's, hypertonic saline; b) adrenergic agents such as norepinephrine, and c) fresh blood. Our results using i) a rat model of fixed pressure blood loss, ii) rabbit model of uncontrolled bleeding with trauma, and iii) a pig model of massive blood loss indicate that centhaquin is highly effective in reducing the mortality following hypovolemic shock (Gulati et al. 
2012, Gulati et al. 2013, Lavhale et al. 2013, Papapanagiotou et al. 2016). Unlike other resuscitative agents (vasopressors) centhaquin increased MAP by increasing stroke volume (SV) and $\mathrm{CO}$; and decreased heart rate and systemic vascular resistance (SVR). Centhaquin is currently in clinical development as a resuscitative agent for hemorrhagic shock. The proposed mechanism is that centhaquin acts on venous $\alpha_{2 B}$ adrenergic receptors to produce constriction and increase venous return to the heart and stimulate central $\alpha_{2 \mathrm{~A}}$ adrenergic receptors to produce a decrease in SVR. However, adrenergic receptors have been shown to be modulated by endothelin (ET) receptors (Gulati 1992, Gulati and Srimal 1993, Lavhale et al. 2010, Sanchez et al. 2014) therefore, it is possible that ET receptors may be involved in the mechanism of action of centhaquin in hemorrhagic shock.

ET is an endogenous peptide which acts on two distinct G-protein-coupled receptors, $\mathrm{ET}_{\mathrm{A}}$ and $\mathrm{ET}_{\mathrm{B}}$, and performs numerous functions throughout the body (Arai et al. 1990, Goto et al. 1989). The elevated plasma ET-1 levels during hemorrhagic shock along with a decrease in blood flow to the kidneys and the lungs have been previously reported (Chang et al. 1993, Edwards et al. 1994). A decrease in pulmonary and renal blood flow following hemorrhagic shock, causing reduced clearance of ET-1, may be responsible for an increase in circulating plasma ET-1 which plays an important role in maintaining vascular tone and tissue blood perfusion (Chang et al. 1993). Circulating ET-1 may regulate cardiovascular system following hemorrhagic shock by acting on $\mathrm{ET}_{\mathrm{A}}$ receptors, as a vasoconstrictor and on $\mathrm{ET}_{\mathrm{B}}$ receptors as a vasodilator to maintain vascular tone (Bourque et al. 2011, Cardillo et al. 2000, Helmy et al. 2001, Sandoo et al. 2010). It is therefore, of interest to investigate the effect of hemorrhagic shock and resuscitation with centhaquin on changes in $\mathrm{ET}_{\mathrm{A}}$ and $\mathrm{ET}_{\mathrm{B}}$ receptors in various tissues. In addition, it is known that hemorrhagic shock and resuscitation contribute towards an increased risk of systemic inflammatory response (Chaudry et al. 1990) and ET-1 plays a pivotal role in inflammation following sepsis and hemorrhagic shock (Kowalczyk et al. 2015).

The present study was conducted to examine the effect of hemorrhagic shock and resuscitation with centhaquin on endothelin $\left(\mathrm{ET}_{\mathrm{A}}\right.$ and $\left.\mathrm{ET}_{\mathrm{B}}\right)$ receptors in various tissues along with concentration of plasma ET-1 and inflammatory makers in a rat model of hemorrhagic shock.

\section{Methods}

Animals

Male Sprague-Dawley rats (340-380 g) (Envigo, Indianapolis, IN, USA) were housed for at least 4 days in a room with controlled temperature $\left(23 \pm 1{ }^{\circ} \mathrm{C}\right)$, humidity $(50 \pm 10 \%)$ and light (6:00 A.M. to 6:00 P.M.) before being used. Food and water were made available continuously. Animal care and use for experimental procedures were approved by the Institutional Animal Care and Use Committee of the Midwestern University. All anesthetic and surgical procedures were in compliance with the guidelines established by the Animal Care Committee.

\section{Drugs and chemicals}

Centhaquin citrate (PMZ-2010) was synthesized at Pharmazz India Private Limited, Greater Noida, India. Urethane (ethyl carbamate) (Sigma-Aldrich, St. Louis, MO, USA), Hypertonic Saline Injection, USP (Hospira, Inc, Lake Forest, IL, USA) and Heparin Sodium Injection, USP (APP Pharmaceuticals, LLC, Schaumburg, IL, USA) were used. Endothelin-1 Enzyme Immunometric Assay Kit (Catalog No. 900-020A, Assay Designs, Inc., Ann Arbor, MI, USA), IL-6 ELISA kit (Catalog No. KRC0061, Invitrogen Corporation, Carlsbad, CA, USA), IL-10 ELISA kit (Catalog No. KRC0101, Invitrogen Corporation, Carlsbad, CA, USA) and TNF- $\alpha$ ELISA kit (Catalog No. ER3TNFA, Thermo Scientific, Rockford, IL, USA) were used for various estimations.

\section{Determination of cardiovascular response}

The animals were anesthetized with urethane dissolved in isotonic saline. Urethane was administered in a dose of $1.5 \mathrm{~g}$ per $\mathrm{kg}$ body weight via intraperitoneal injection. Urethane was selected as an anesthetic agent, because it produces long lasting (8-10 h) anesthesia with minimal cardiovascular and respiratory system depression. It produces a level of surgical anesthesia characterized by preservation of cardiovascular reflexes (Maggi and Meli 1986). Briefly, anaesthetized rats were immobilized on a surgical board equipped with controlled heating pad. Blood $\mathrm{pO}_{2}, \mathrm{pCO}_{2}$ and $\mathrm{pH}$, were maintained using a tracheotomy cannula connected to a rodent ventilator (Model 683, Harvard Apparatus Inc., Holliston, MA, USA). The right carotid artery was exposed to measure the left ventricular performance. Surgical suture (Deknatel, Research Triangle Park, NC, USA) was 
secured around the proximal end of the carotid artery and an ultra-miniature pressure-volume $(\mathrm{P}-\mathrm{V})$ catheter SPR-869 (Millar Instruments, Houston, TX, USA) was inserted through a tiny incision made near the proximal end of the artery. The P-V terminal of the catheter was connected to MPVS-300 P-V unit through PEC-4D and CEC-4B cables and advanced into the left ventricle to obtain the P-V signals. The signals were continuously aquired $\left(1000 \mathrm{~S}^{-1}\right)$ using the MPVS-300 P-V unit (AD Instruments, Mountain View, CA, USA) and PowerLab 16/30 data acquisition system (AD Instruments). MAP and HR were measured by cannulating the left femoral artery with pressure catheter SPR-320 (Millar Instruments), connected to the ML221 bridge amplifier (AD Instruments) through AEC-10C connector and the signals were acquired $\left(1000 \mathrm{~S}^{-1}\right)$ using PowerLab 16/30 data acquisition system (Gulati et al. 2012, Pacher et al. 2008). The left femoral vein was cannulated using PE 50 tubing (Clay Adams, Parsipanny, NJ, USA) and secured for resuscitation.

\section{Determination of arterial blood gases and base deficit}

Baseline arterial blood $\mathrm{pH}, \mathrm{pO}_{2}, \mathrm{pCO}_{2}, \mathrm{Na}^{+}, \mathrm{K}^{+}$ and lactate were monitored prior to induction of shock, $30 \mathrm{~min}$ after induction of shock, and 30 and $60 \mathrm{~min}$ following vehicle or centhaquin resuscitation. Blood samples $(0.15 \mathrm{ml})$ were drawn from the arterial cannula using blood gas sampling syringes (Innovative Medical Technologies, Inc. Leawood, KS, USA) and analyzed using a pHOx Ultra analyzer (Nova Biomedical Corporation, Waltham, MA, USA). The base deficit was calculated using the formula (Davis et al. 1998, Paladino et al. 2008):

$$
\mathrm{SBD}=0.9287 \times\left[\mathrm{HCO}_{3}{ }^{-}-24.4+14.83 \times(\mathrm{pH}-7.4)\right]
$$

\section{Induction of hemorrhagic shock}

Hemorrhage was induced by withdrawing blood from the femoral artery at a rate of approximately 0.5 to $1 \mathrm{ml} / \mathrm{min}$ until a MAP of $35 \mathrm{~mm} \mathrm{Hg}$ was reached. This MAP was maintained for 30 min by further withdrawal of blood, if necessary. The hemorrhagic shock model used in the present study is a well-established rodent model of manageable pressure hemorrhage (Buehler et al. 2000, Gulati et al. 1997a, Gulati and Sen 1998). The volume of blood loss was about $\sim 8.0 \mathrm{ml}$ in each rat and was similar in various groups, amounting to approximately $40 \%$ of the total blood. Measured hematocrit levels were similar in various groups. The duration of blood withdrawal was approximately $15 \mathrm{~min}$.

\section{Experimental design}

To determine the resuscitative effect of centhaquin on cardiovascular system and plasma cytokines in hemorrhagic shock, rats were randomly divided into five groups. Group 1: Sham control (Non-hemorrhaged) $(\mathrm{n}=5)$, Group 2: Hemorrhage with no resuscitation ( $\mathrm{n}=5)$; Group 3: Hemorrhage followed by resuscitation with $3 \%$ hypertonic saline (vehicle) ( $\mathrm{n}=5$ ); Group 4: Hemorrhage followed by resuscitation with vehicle plus centhaquin $(0.017 \mathrm{mg} / \mathrm{kg})(\mathrm{n}=5)$; and Group 5: Hemorrhage followed by resuscitation with vehicle plus centhaquin $(0.05 \mathrm{mg} / \mathrm{kg})$ $(\mathrm{n}=5)$. Resuscitation was started $30 \mathrm{~min}$ after induction of hemorrhagic shock as an intravenous infusion $(1 \mathrm{ml} / \mathrm{min})$ through femoral vein using an infusion pump (Harvard Apparatus Infusion/Withdrawal Pump, Millis, MA, USA). The blood samples, for biochemical estimations, were collected at $30 \mathrm{~min}$ of resuscitation and cardiovascular parameters were monitored till $60 \mathrm{~min}$ after which the animal was sacrificed. The volume of resuscitative solution was kept equal to the volume of blood loss. Although, this does not represent a typical human resuscitation, but this volume was selected to minimize confounding factors and allow a more accurate determination of resuscitative effect of centhaquin.

\section{Determination of ET-1 level in the blood plasma}

In order to analyze the change in plasma ET-1 level after hemorrhage followed by centhaquin resuscitation, blood samples were collected from rats of various groups $30 \mathrm{~min}$ after resuscitation and were collected into chilled EDTA tubes ( $1 \mathrm{mg} \cdot \mathrm{ml}^{-1}$ of blood) containing aprotinin (500 KIU.ml ${ }^{-1}$ of blood). The blood samples were centrifuged at $1,600 \mathrm{x}$ g for $15 \mathrm{~min}$ at $0{ }^{\circ} \mathrm{C}$ and plasma ET-1 level was estimated using enzyme immunoassay. Briefly, plasma samples and standards were added to wells coated with a monoclonal antibody specific for ET-1. The plate was then washed after $24 \mathrm{~h}$ of incubation and horseradish peroxidase (HRP) labeled monoclonal antibody was then added. After $30 \mathrm{~min}$ incubation the plate was washed and a solution of 3,3',5,5' tetramethylbenzidine substrate was added which generates a blue color. Hydrochloric acid $(1 \mathrm{~N})$ was added to stop the substrate reaction and the resulting yellow color was read at $450 \mathrm{~nm}$ using DTX 800 Multimode detector and the data was analyzed with Multimode Detection Software (Beckman Coulter, Inc., Harbor Boulevard, Fullerton, CA, USA). The measured optical density is directly proportional to the concentration of ET-1 (Lavhale et al. 2010). 


\section{Estimation of $E T_{A}$ and $E T_{B}$ receptor expression}

Expression of $\mathrm{ET}_{\mathrm{A}}$ and $\mathrm{ET}_{\mathrm{B}}$ receptors was determined using the Western blotting technique (Briyal et al. 2015, Leonard and Gulati 2013) with some modifications. After completion of cardiovascular experiments animals were sacrificed and the organs (brain, heart, liver, lung, kidney and abdominal aorta) were immediately dissected out, flash frozen on dry ice, and stored at $-80{ }^{\circ} \mathrm{C}$ for further analysis. The tissue was homogenized with 10x (w/v) RIPA lysis buffer $(20 \mathrm{mM}$ Tris- $\mathrm{HCl} \mathrm{pH} 7.5,120 \mathrm{mM} \mathrm{NaCl}, 1.0 \%$ TritonX-100, $1.0 \%$ sodium deoxycholate, $0.1 \%$ sodium dodecyl sulfate (SDS), $10 \%$ glycerol, $1 \mathrm{mM}$ disodium ethylene diamine tetraacetic acid (EDTA), $1 \mathrm{mM}$ ethylene glycol-bis( $\beta$-aminoethyl ether)-N,N,N',N'-tetraacetic acid tetrasodium salt (EGTA), phosphatase inhibitors and Complete Mini Protease inhibitor cocktail tablet (Roche Diagnostics, Indianapolis, IN, USA). Proteins were isolated in solubilized form and concentrations were measured by Folin-Ciocalteu's phenol reagent (Lowry et al. 1951). Solubilized protein $(60 \mu \mathrm{g})$ was denatured in Laemmli sample buffer (Bio-Rad Laboratories, Hercules, CA, USA), resolved on $10 \%$ sodium dodecyl sulfatepolyacrylamide gel electrophoresis (SDS-PAGE) and then transferred onto the nitrocellulose membrane followed by blocking the membrane with SuperBlock ${ }^{\circledR}$ Blocking Buffer in Tris-buffered saline (TBS) (ThermoFisher Scientific, Hanover Park, IL, USA). The membranes were washed three times with 1x TBS-Tween (TBST) and incubated with rabbit polyclonal anti-ET $\mathrm{A}_{\mathrm{A}}$ receptor (ab85163, Abcam, Cambridge, MA, USA, $1: 1000)$ or anti-ET $\mathrm{B}_{\mathrm{B}}$ receptor (ab117529, Abcam, Cambridge, MA, USA, 1:1000) or mouse monoclonal anti- $\beta$-actin (a1978, Sigma-Aldrich, St. Louis, MO, USA) antibodies, followed by horseradish peroxidase (HRP)conjugated secondary antibodies goat anti-rabbit (sc2004, Santa Cruz Biotechnology, Dallas, TX, USA, 1:2000) or goat anti-mouse (ab98693, Abcam, Cambridge, MA, USA, 1:10,000) and visualized by SuperSignal ${ }^{\circledR}$ West Pico Chemiluminescent Substrate (ThermoFisher Scientific, Hanover Park, IL, USA) using the ChemiDoc $^{\mathrm{TM}}$ MP Imaging System (Bio-Rad Laboratories, Hercules, CA, USA) and then analyzed using ImageJ (NIH) software.

Determination of IL-6, IL-10 and TNF- $\alpha$ levels in the blood plasma

Plasma levels of IL-6, IL-10 and TNF- $\alpha$ were estimated using commercially available rat enzyme- linked immunosorbent assay kits: IL-6 (Invitrogen Corporation, with a lower detection limit of $5 \mathrm{pg} / \mathrm{ml}$; highly specific for rat IL-6 with no cross-reactivity with other cytokines), IL-10 (Invitrogen Corporation, with a lower detection limit of $5 \mathrm{pg} / \mathrm{ml}$; highly specific for rat IL-10 with no cross-reactivity with other cytokines) and TNF- $\alpha$ ELISA kit (Thermo Scientific, with a lower detection limit of $15 \mathrm{pg} / \mathrm{ml}$; highly specific for rat TNF- $\alpha$ with no cross-reactivity with other cytokines) were used for various estimations. All assays were performed using plasma samples that have not been thawed previously according to the protocols provided by the manufacturers.

\section{Statistical analysis}

A Power Analysis was conducted using GraphPad Instat-2.00. The power was set to $80 \%$ (beta $=0.8$ ) and the level of significance (alpha) used was 0.05. Power Analysis indicated that a sample size of 5 for cardiovascular and 4 for biochemical estimation per group was sufficient to achieve a power of $80 \%$, when level of significance alpha $=0.05$. Data are presented as mean \pm SEM. The significance of differences was estimated by one-way analysis of variance followed by a post hoc test (Bonferroni's method). A $P$ value of less than 0.05 was considered to be significant. The statistical analysis was processed with GraphPad Prism 7.00 (GraphPad, San Diego, CA, USA).

\section{Results}

Effect of centhaquin on arterial blood $p H, \mathrm{pO}_{2}, \mathrm{pCO}_{2}$, hematocrit, blood lactate and base-deficit of hemorrhaged rats

A significant reduction in blood $\mathrm{pH}$ was observed in rats following hemorrhage, which was further decreased following administration of hypertonic saline. Centhaquin administration (0.017 and $0.05 \mathrm{mg} / \mathrm{kg})$ significantly prevented the reduction of $\mathrm{pH}$ in hemorrhaged rats. Hemorrhage produced a significant decrease in $\mathrm{pCO}_{2}$ and increase in $\mathrm{pO}_{2}$ which was not affected by resuscitation with hypertonic saline or centhaquin (Table 1).

There was no change in percent hematocrit in control rats throughout the experimental period, while hematocrit lowered significantly $(\mathrm{p}<0.001)$ after hemorrhage. Hemorrhaged rats, when resuscitated with hypertonic saline or with 0.017 and $0.05 \mathrm{mg} / \mathrm{kg}$ doses of centhaquin showed no change in hematocrit after treatment. 
Table 1. Effect of centhaquin on hematocrit, arterial blood $\mathrm{pH}, \mathrm{pCO}_{2}, \mathrm{pO}_{2}$, lactate and base deficit levels in hemorrhaged rats.

\begin{tabular}{|c|c|c|c|c|c|c|}
\hline & Time & $\begin{array}{l}\text { Sham } \\
\text { Control }\end{array}$ & $\begin{array}{c}\text { Hemorrhage } \\
\text { (no resuscitation) }\end{array}$ & $\begin{array}{l}\text { Hemorrhage } \\
\text { (3\% saline) }\end{array}$ & $\begin{array}{l}\text { Hemorrhage } \\
\text { (centhaquin; } \\
0.017 \mathrm{mg} / \mathrm{kg} \text { ) }\end{array}$ & $\begin{array}{l}\text { Hemorrhage } \\
\text { (centhaquin; } \\
0.05 \mathrm{mg} / \mathrm{kg} \text { ) }\end{array}$ \\
\hline Hematocrit & Baseline & $36.0 \pm 2.4$ & $38.3 \pm 0.8$ & $38.3 \pm 0.8$ & $36.8 \pm 1.3$ & $39.3 \pm 1.6$ \\
\hline \multirow[t]{2}{*}{$(\%)$} & H. shock & $38.3 \pm 0.8$ & $24.7 \pm 2.4^{*}$ & $22.2 \pm 1.5^{*}$ & $24.8 \pm 1.5^{*}$ & $22.2 \pm 0.7^{*}$ \\
\hline & $60 \min$ & $36.5 \pm 1.5$ & & $19.5 \pm 1.8$ & $21.5 \pm 1.8$ & $21.3 \pm 1.3$ \\
\hline \multirow[t]{3}{*}{$p H$} & Baseline & $7.40 \pm 0.01$ & $7.36 \pm 0.01$ & $7.37 \pm 0.01$ & $7.38 \pm 0.01$ & $7.38 \pm 0.01$ \\
\hline & H. shock & $7.39 \pm 0.01$ & $7.22 \pm 0.02^{*}$ & $7.17 \pm 0.03^{*}$ & $7.23 \pm 0.02^{*}$ & $7.25 \pm 0.03^{*}$ \\
\hline & $60 \mathrm{~min}$ & $7.38 \pm 0.01$ & & $7.13 \pm 0.02$ & $7.24 \pm 0.02^{\Delta}$ & $7.28 \pm 0.01^{\Delta}$ \\
\hline $\mathrm{pCO}_{2}$ & Baseline & $32.5 \pm 2.1$ & $33.6 \pm 1.1$ & $33.3 \pm 1.2$ & $33.8 \pm 1.2$ & $34.5 \pm 2.1$ \\
\hline \multirow[t]{2}{*}{$(\mathrm{mm} \mathrm{Hg})$} & H. shock & $29.3 \pm 2.1$ & $15.8 \pm 0.7^{*}$ & $15.9 \pm 1.1^{*}$ & $15.9 \pm 0.9^{*}$ & $16.3 \pm 1.5^{*}$ \\
\hline & $60 \mathrm{~min}$ & $30.8 \pm 2.2$ & & $27.8 \pm 2.8^{\#}$ & $26.0 \pm 1.6^{\#}$ & $27.3 \pm 1.9^{\#}$ \\
\hline $\mathrm{pO}_{2}$ & Baseline & $122.2 \pm 4.3$ & $125.9 \pm 5.7$ & $120.3 \pm 1.2$ & $125.5 \pm 1.9$ & $120.2 \pm 1.2$ \\
\hline \multirow[t]{2}{*}{$(m m H g)$} & H. shock & $121.7 \pm 3.9$ & $142.6 \pm 1.3^{*}$ & $140.3 \pm 5.6^{*}$ & $145.6 \pm 1.9^{*}$ & $142.8 \pm 1.8^{*}$ \\
\hline & $60 \mathrm{~min}$ & $112.3 \pm 3.9$ & & $128.3 \pm 4.8$ & $131.3 \pm 5.4^{\#}$ & $121.3 \pm 4.6^{\#}$ \\
\hline Lactate & Baseline & $1.9 \pm 0.2$ & $1.8 \pm 0.1$ & $1.9 \pm 0.1$ & $1.5 \pm 0.2$ & $1.8 \pm 0.1$ \\
\hline \multirow[t]{2}{*}{$(\mathrm{mmol} / \mathrm{l})$} & H. shock & $1.7 \pm 0.1$ & $7.4 \pm 0.2^{*}$ & $7.3 \pm 0.2^{*}$ & $7.6 \pm 0.3^{*}$ & $7.4 \pm 0.4^{*}$ \\
\hline & $60 \mathrm{~min}$ & $1.2 \pm 0.1$ & & $3.7 \pm 0.2^{\#}$ & $1.9 \pm 0.1^{\# \Delta}$ & $1.7 \pm 0.2^{\# \Delta}$ \\
\hline Base-deficit & Baseline & $-2.7 \pm 0.4$ & $-2.4 \pm 0.3$ & $-2.4 \pm 0.4$ & $-2.9 \pm 0.3$ & $-2.8 \pm 0.3$ \\
\hline \multirow[t]{2}{*}{$(m E q / l)$} & H. shock & $-2.9 \pm 0.5$ & $-15.7 \pm 1.5^{*}$ & $-16.1 \pm 0.6^{*}$ & $-15.3 \pm 0.4^{*}$ & $-15.4 \pm 0.9^{*}$ \\
\hline & $60 \mathrm{~min}$ & $-3.9 \pm 0.4$ & & $-16.3 \pm 1.3$ & $-12.0 \pm 0.2^{\# \Delta}$ & $-11.6 \pm 0.5^{\# \Delta}$ \\
\hline$E T-1$ & $60 \mathrm{~min}$ & $13.6 \pm 0.9$ & $21.8 \pm 0.9^{*}$ & $25.3 \pm 1.35^{*}$ & $37.9 \pm 3.0^{* \# \Delta}$ & $38.3 \pm 2.7^{* \# \Delta}$ \\
\hline
\end{tabular}

The values are expressed as mean \pm SEM. ${ }^{*} p<0.05$ compared to baseline; ${ }^{*} p<0.05$ compared to hemorrhage; ${ }^{\Delta} p<0.05$ compared to vehicle treated group.

There was no change in blood lactate levels in control rats throughout the experimental period, while lactate levels were significantly increased $(p<0.001)$ following hemorrhage. Hemorrhaged rats, when resuscitated with 0.017 and $0.05 \mathrm{mg} / \mathrm{kg}$ doses of centhaquin showed a significant decrease $(p<0.001)$ in blood lactate levels compared to the hypertonic saline group (Table 1). There was no change in base deficit of control rats during the experimental period. Base deficit significantly $(\mathrm{p}<0.001)$ increased after induction of hemorrhage, which was not affected by resuscitation with hypertonic saline. Rats resuscitated with 0.017 and $0.05 \mathrm{mg} / \mathrm{kg}$ doses of centhaquin, on the other hand, showed a significant decrease $(p<0.001)$ in base deficit $(-12.0 \pm 0.2$ and $-11.6 \pm 0.5$, respectively) compared to hypertonic saline $(-16.3 \pm 1.3)$ (Table 1). Hemorrhaged rats that were not resuscitated could not survive till $60 \mathrm{~min}$ and hence no data could be obtained at that time point.
Effect of centhaquin on mean arterial pressure and heart rate of hemorrhaged rats

Control rats did not show any change in MAP during the experimental period. MAP significantly decreased $(p<0.001)$ in all the treatment groups after induction of hemorrhage. Hemorrhaged rats, resuscitated with hypertonic saline, did not show any improvement in MAP at either 30 or 60 min post resuscitation. Rats resuscitated with centhaquin $(0.017$ and $0.05 \mathrm{mg} / \mathrm{kg})$ showed a significant increase $(\mathrm{p}<0.01)$ in MAP for at least $60 \mathrm{~min}$ post resuscitation (Fig. 1). Prior to hemorrhage, the baseline HR was approximately 345 beats $/$ min in all groups. Hemorrhage produced a slight increase in HR $(\sim 372$ beats $/ \mathrm{min})$. In rats resuscitated with hypertonic saline HR dropped to $353 \pm 11$ beats/min at $60 \mathrm{~min}$, while in rats resuscitated with centhaquin in the doses of 0.017 and $0.05 \mathrm{mg} / \mathrm{kg} \mathrm{HR}$ was $361 \pm 10$ and $363 \pm 10$, respectively (Fig. 1). No significant difference was observed in HR following resuscitation with hypertonic saline or centhaquin. 

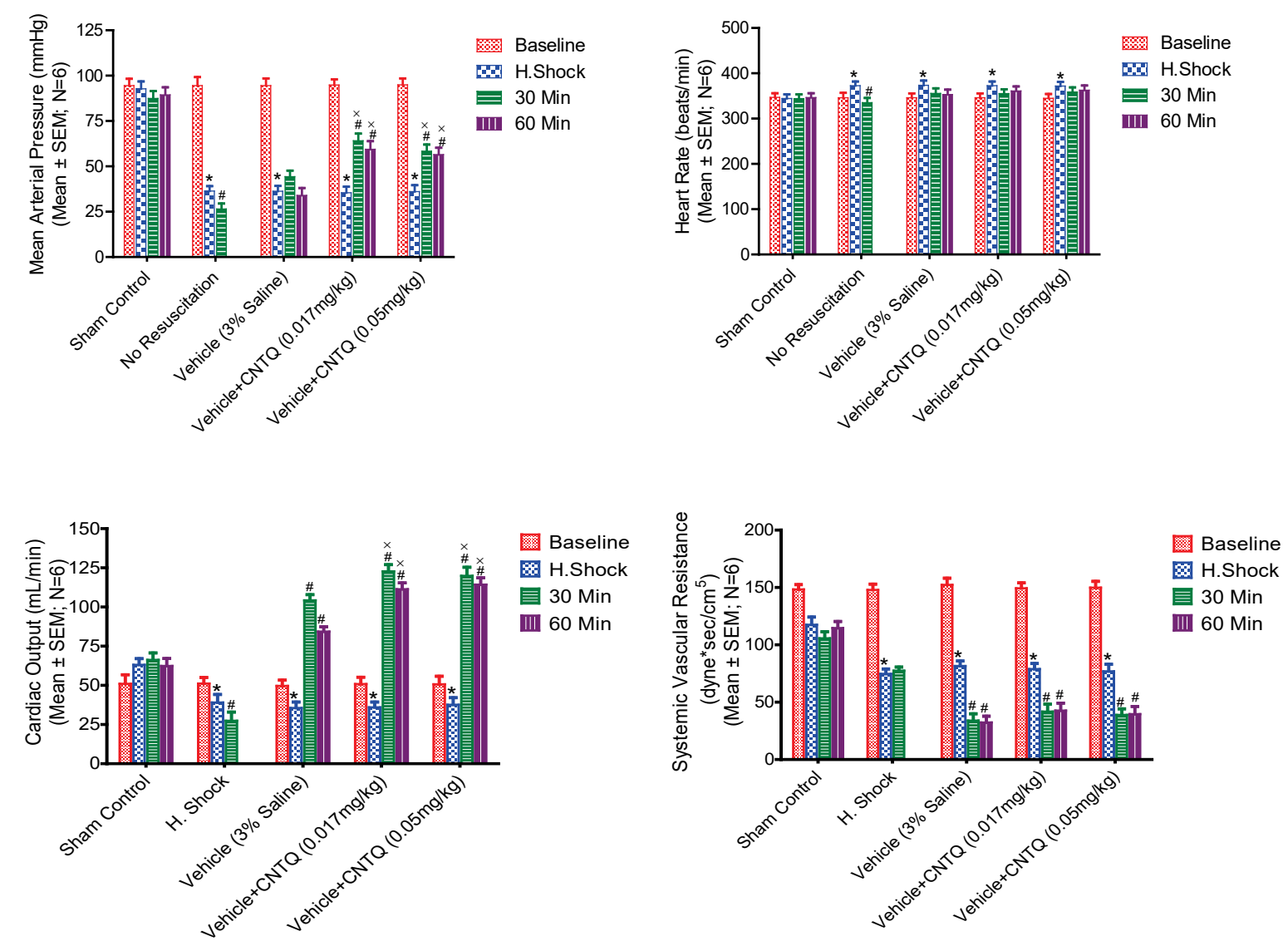

Fig. 1. Effect of hemorrhage on mean arterial pressure, heart rate, cardiac output and systemic vascular resistance in sham and hemorrhaged rats. Hemorrhaged rats were resuscitated with hypertonic saline or centhaquin. The values are expressed as mean \pm SEM. $(n=5) .{ }^{*} p<0.05$ compared to baseline, ${ }^{\#} p<0.05$ compared to hemorrhage, ${ }^{x} p<0.05$ compared to vehicle treated group.

Effect of centhaquin on cardiac output and systemic vascular resistance of hemorrhaged rats

CO significantly decreased following hemorrhage in all the groups. Hemorrhaged rats resuscitated with hypertonic saline and centhaquin both produced a significant increase in $\mathrm{CO}$. Centhaquin resuscitation significantly increased $\mathrm{CO}$ at 30 and $60 \mathrm{~min}$ post resuscitation as compared to hypertonic saline alone. SVR decreased from $148 \pm 5$ to $77 \pm 3$ dyne* $\mathrm{sec} / \mathrm{cm}^{5}$ following hemorrhage, and it further decreased at 30 and $60 \mathrm{~min}$ of resuscitation with both hypertonic saline or centhaquin treatments (Fig. 1).

\section{Effect of centhaquin on plasma ET-1 level of hemorrhaged rats}

The baseline plasma ET-1 levels were 13.6 \pm 0.87 pg. $\mathrm{ml}^{-1}$. After hemorrhage, ET-1 levels were significantly increased to $21.8 \pm 0.87$ pg. $\mathrm{ml}^{-1}(\mathrm{p}<0.001)$. In rats treated with hypertonic saline, ET-1 levels were $25.3 \pm 1.35$ pg.ml ${ }^{-1}$, with no significant change compared to the untreated hemorrhagic shock group. However, in rats treated with centhaquin $(0.017$ and $0.05 \mathrm{mg} / \mathrm{kg})$, the ET-1 levels were significantly increased $(37.9 \pm 3.03$ and
$38.3 \pm 2.7$ pg. $\mathrm{ml}^{-1}$, respectively) compared to hemorrhaged rats resuscitated with hypertonic saline (Table 1).

\section{Effect of centhaquin on the expression of $E T_{A}$ receptors in} hemorrhaged rats

There was no change in the expression of $\mathrm{ET}_{\mathrm{A}}$ receptors in the brain, heart, liver, lungs and kidney cortex (Fig. 2). A significant $(\mathrm{p}<0.0001)$ increase in the expression of $\mathrm{ET}_{\mathrm{A}}$ receptors was observed following hemorrhagic shock in the abdominal aorta. The expression of $\mathrm{ET}_{\mathrm{A}}$ receptors in the abdominal aorta of hemorrhaged rats increased by $140 \%$ compared to sham group. In hemorrhaged rats treated with hypertonic saline and hypertonic saline + centhaquin $(0.017$ and 0.05 $\mathrm{mg} / \mathrm{kg})$, a significant decrease $(-48.8,-47.6$ and $-49.2 \%$, respectively) in $\mathrm{ET}_{\mathrm{A}}$ expression was observed in the abdominal aorta compared to hemorrhaged rats with no treatment. No change in $\mathrm{ET}_{\mathrm{A}}$ expression was observed in the renal medulla following hemorrhagic shock in rats. However, rats treated with centhaquin (0.017 and $0.05 \mathrm{mg} / \mathrm{kg}$ ) presented with a significant decrease (-61.3\% and $-70.5 \%$, respectively) in the expression of $\mathrm{ET}_{\mathrm{A}}$ receptors compared to hemorrhagic shock (Fig. 2). 

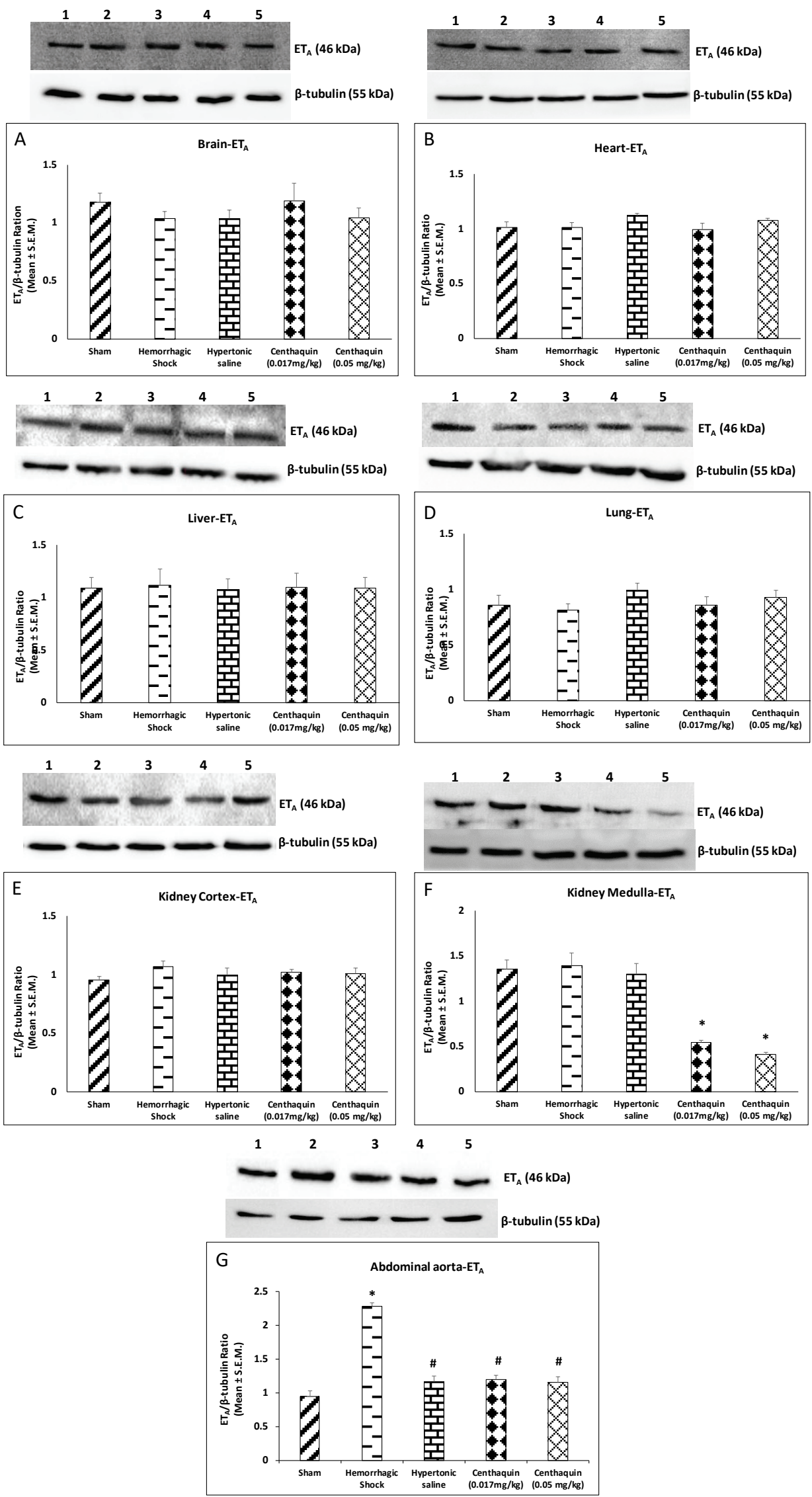

Fig. 2. Effect of hemorrhage on the expression of $\mathrm{ET}_{\mathrm{A}}$ receptors in sham and hemorrhaged rats. Hemorrhaged rats were resuscitated with hypertonic saline or centhaquin. Lane 1 - Sham, Lane 2 - Hemorrhagic shock, Lane 3 - Hypertonic saline (vehicle), Lane 4 Vehicle + centhaquin $(0.017 \mathrm{mg} / \mathrm{kg})$, Lane $5-$ Vehicle + centhaquin $(0.05 \mathrm{mg} / \mathrm{kg})$. The values are expressed as mean \pm SEM. $(n=4)$. ${ }^{*} \mathrm{p}<0.05$ compared to sham, ${ }^{*} \mathrm{p}<0.05$ compared to hemorrhage or hypertonic saline. 

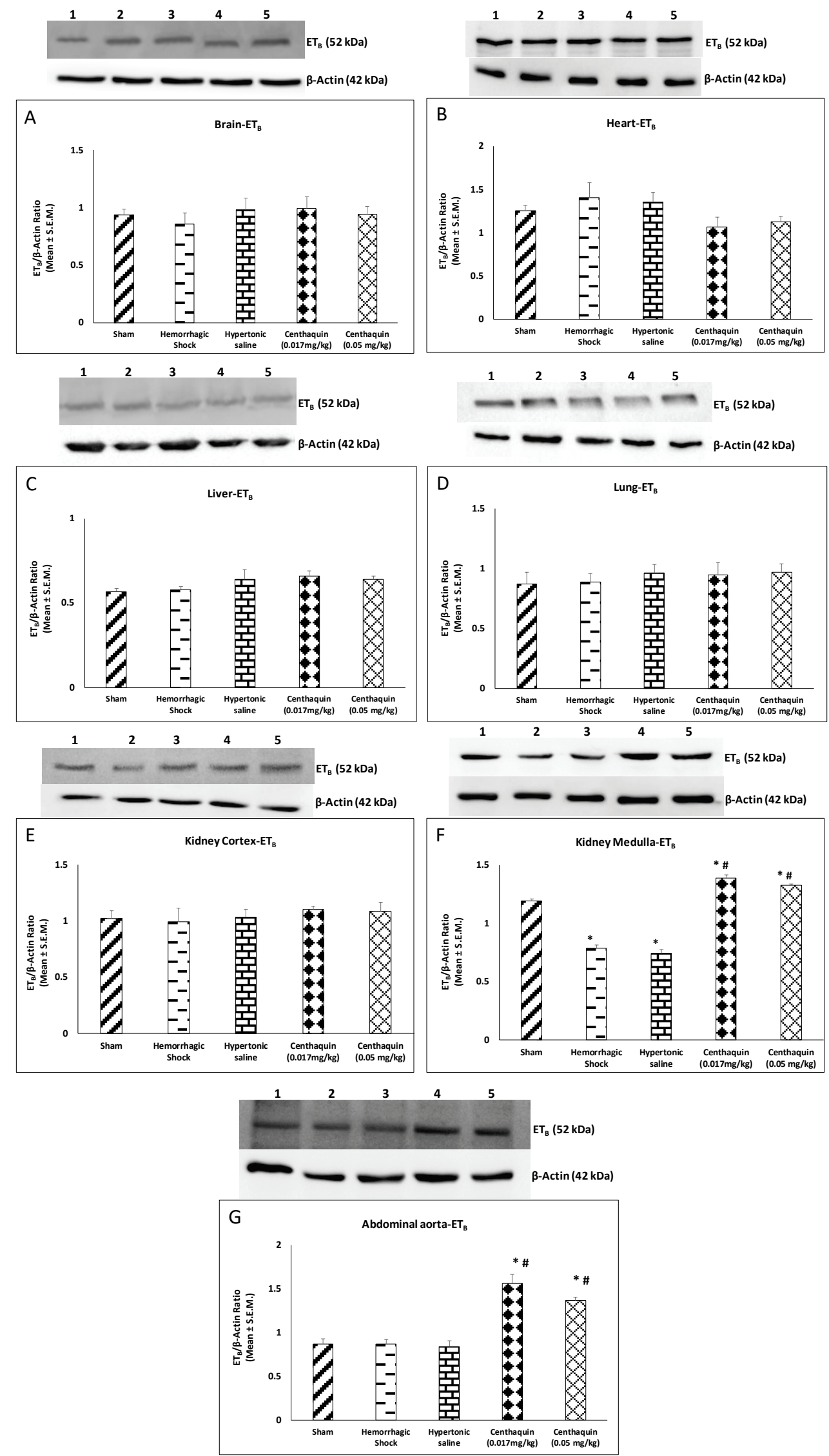

Fig. 3. Effect of hemorrhage on the expression of $\mathrm{ET}_{\mathrm{B}}$ receptors in sham and hemorrhaged rats. Hemorrhaged rats were resuscitated with hypertonic saline or centhaquin. Lane 1 - Sham, Lane 2 - Hemorrhagic shock, Lane 3 - Hypertonic saline (vehicle), Lane 4 Vehicle + centhaquin $(0.017 \mathrm{mg} / \mathrm{kg})$, Lane $5-$ Vehicle + centhaquin $(0.05 \mathrm{mg} / \mathrm{kg})$. The values are expressed as mean $\pm \mathrm{SEM}$. $(n=4)$. ${ }^{*} p<0.05$ compared to sham, ${ }^{\#} p<0.05$ compared to hemorrhage or hypertonic saline. 

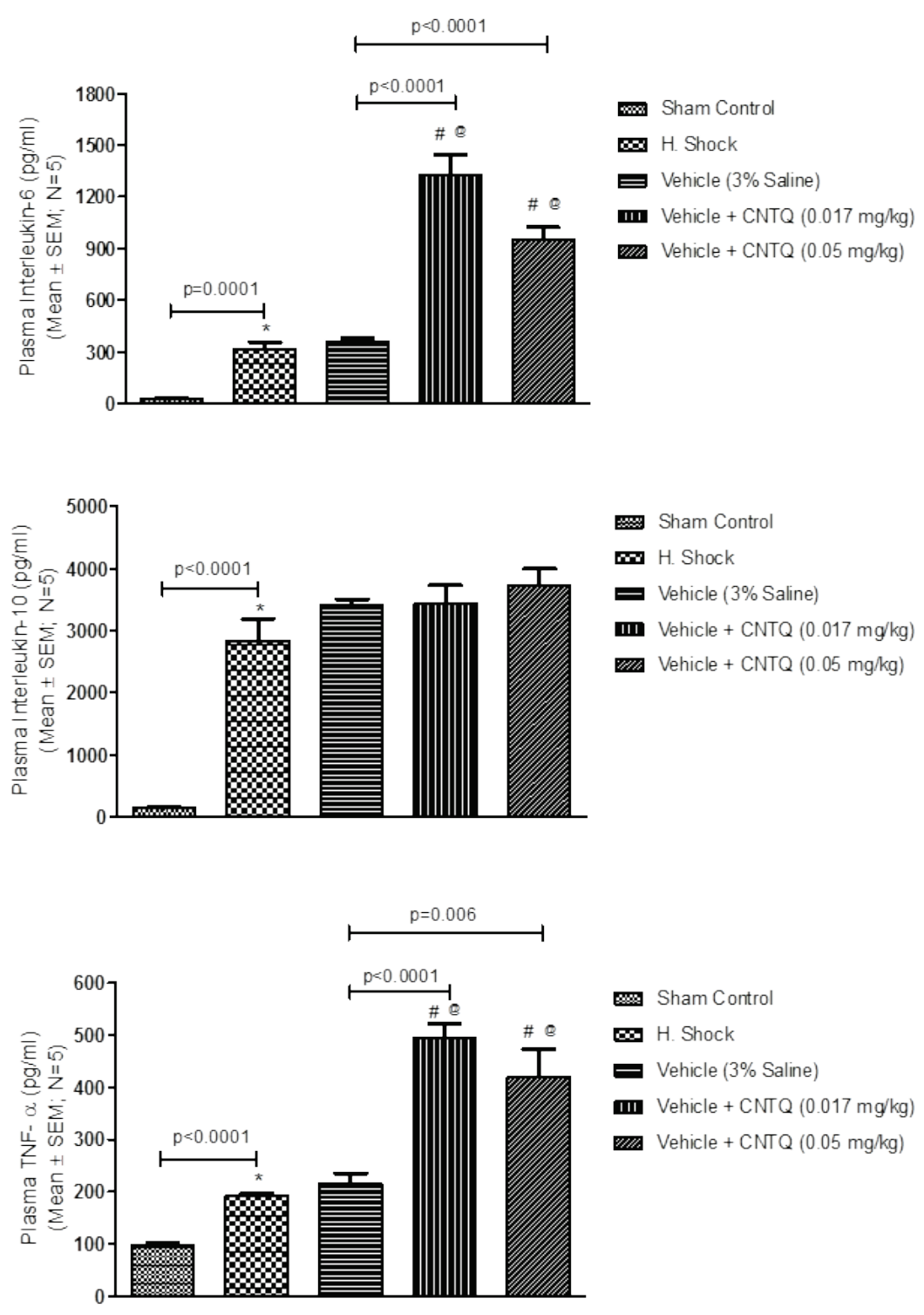

Fig. 4. Effect of hemorrhage on plasma TNF-a, IL-6 and IL-10 in sham and hemorrhaged rats. Hemorrhaged rats were resuscitated with hypertonic saline or centhaquin. The values are expressed as mean \pm SEM. $(n=5) .{ }^{*} p<0.05$ compared to sham, ${ }^{*} p<0.05$ compared to hemorrhage, ${ }^{\circledR} p<0.05$ compared to hypertonic saline.
Effect of centhaquin on the expression of $E T_{B}$ receptors in hemorrhaged rats

There was no change in the expression of $\mathrm{ET}_{\mathrm{B}}$ receptors in brain, heart, liver, lungs and kidney cortex (Fig. 3). No change in $\mathrm{ET}_{\mathrm{B}}$ expression was observed in the abdominal aorta following hemorrhagic shock in rats. However, the expression of $\mathrm{ET}_{\mathrm{B}}$ receptors in abdominal aorta of rats treated with centhaquin $(0.017$ and 0.05 $\mathrm{mg} / \mathrm{kg}$ ) significantly increased $(79.7 \%$ and $57.4 \%$, respectively) compared untreated hemorrhaged rats. A significant $(\mathrm{p}<0.0001)$ decrease $(-34 \%)$ in the expression of $\mathrm{ET}_{\mathrm{B}}$ receptors was observed following hemorrhagic shock in kidney medulla compared to the sham group. In hemorrhaged rats treated with centhaquin $(0.017$ and $0.05 \mathrm{mg} / \mathrm{kg})$, a significant increase $(76.6 \%$ and $69.4 \%$, respectively) in $\mathrm{ET}_{\mathrm{B}}$ expression was observed in the kidney medulla compared to untreated hemorrhaged rats (Fig. 3).
Effect of centhaquin on plasma IL-6, IL-10 and TNF- $\alpha$ levels of hemorrhaged rats

To further evaluate whether centhaquin treatment affected the inflammatory response, we measured a select panel of cytokines in rat plasma. Overall, the levels of plasma IL-6, IL-10 and TNF- $\alpha$ were increased in all hemorrhaged rats with or without resuscitation with hypertonic saline and centhaquin. TNF- $\alpha$ and IL-6 levels were higher after hemorrhagic shock and resuscitation with hypertonic saline compared with sham control. Centhaquin further increased $(p<0.01)$ the levels of TNF- $\alpha$ and IL- 6 as compared to hypertonic saline alone. There was no statistically significant difference in plasma IL-10 between rats after hemorrhagic shock and resuscitation with hypertonic saline or centhaquin (Fig. 4). 


\section{Discussion}

Centhaquin significantly decreased blood lactate and restored MAP and enhanced the resuscitative effect of hypertonic saline confirming our previous findings (Gulati et al. 2012, Gulati et al. 2013, Lavhale et al. 2013, Papapanagiotou et al. 2016). The effect of hemorrhagic shock and resuscitation using hypertonic saline alone or with centhaquin on $\mathrm{ET}_{\mathrm{A}}$ and $\mathrm{ET}_{\mathrm{B}}$ receptors expression in different tissues, plasma ET-1 levels and inflammatory markers were determined. We found that $\mathrm{ET}_{\mathrm{A}}$ and $\mathrm{ET}_{\mathrm{B}}$ receptors in the abdominal aorta and renal medulla appear to be involved in its resuscitative action. No change in $\mathrm{ET}_{\mathrm{A}}$ or $\mathrm{ET}_{\mathrm{B}}$ receptor levels were observed in the brain, heart, lung and liver following hemorrhagic shock or resuscitation with either hypertonic saline or centhaquin.

Vascular $\mathrm{ET}_{\mathrm{A}}$ receptors have been well established to have a strong vasoconstrictor effect (Schneider et al. 2007). Hemorrhage produced an increase in the expression of $\mathrm{ET}_{\mathrm{A}}$ receptors in the abdominal aorta. Resuscitation with hypertonic saline and centhaquin significantly reversed the hemorrhageinduced increase in $\mathrm{ET}_{\mathrm{A}}$ receptor expression in the abdominal aorta. However, $\mathrm{ET}_{\mathrm{B}}$ receptors were unaltered following hemorrhagic shock, but were increased by centhaquin treatment. It is possible that following hemorrhagic shock an increase in the expression of vasoconstrictor $\mathrm{ET}_{\mathrm{A}}$ receptors in the blood vessels occurs to maintain vascular tone and MAP. However, an increase in circulating ET-1 along with increased vascular $\mathrm{ET}_{\mathrm{A}}$ receptors may produce undesired vasoconstriction and reduce tissue perfusion. On the other hand, an increase in plasma ET-1 levels following hemorrhagic shock has been reported to be acting as a compensatory mechanism to maintain blood pressure (Chang et al. 1993, Edwards et al. 1994, Gulati et al. 1997b, Sharma et al. 2002). It was also found that a precursor of ET-1 improved the resuscitative effect of hemoglobin based blood-substitute diaspirin cross-linked hemoglobin in severely hemorrhaged rats (Gulati et al. 1995). In normal rats ET-1 produces a biphasic response: an initial transient decrease followed by a sustained increase in blood pressure (Gardiner et al. 1994, Yanagisawa et al. 1988), however, in hemorrhaged rats, ET-1 produced a monophasic effect where only an increase in blood pressure was observed along with improved survival (Jochem et al. 2003). The resuscitative effect of ET-1 in hemorrhaged rats was mediated through $\mathrm{ET}_{\mathrm{A}}$ receptors since it was blocked by $\mathrm{BQ} 123$, a specific $\mathrm{ET}_{\mathrm{A}}$ receptor antagonist (Jochem et al. 2003). It can be speculated that vascular $\mathrm{ET}_{\mathrm{A}}$ receptors are increased following hemorrhagic shock as part of compensatory mechanism which is reversed upon resuscitation with either hypertonic saline or centhaquin. $\mathrm{ET}_{\mathrm{B}}$ receptors in the abdominal aorta were unaltered following hemorrhagic shock, but increased by centhaquin and not by hypertonic saline resuscitation. Since vascular $\mathrm{ET}_{\mathrm{B}}$ receptors produce vasodilation (Arai et al. 1990, Cardillo et al. 2000, Yanagisawa et al. 1988) therefore centhaquin induced increase in the expression of vascular $\mathrm{ET}_{\mathrm{B}}$ receptors may contribute towards an increase in tissue blood perfusion thereby decreasing blood lactate levels of hemorrhaged rats.

ET receptors crosstalk with each other and with adrenergic receptors. The effect of $\mathrm{ET}_{\mathrm{B}}$ receptor desensitization is revealed in the presence of $\mathrm{ET}_{\mathrm{A}}$ receptor blockade (Mickley et al. 1997). On the other hand, $\mathrm{ET}_{\mathrm{B}}$ receptors are capable of altering the pharmacology of $\mathrm{ET}_{\mathrm{A}}$ receptors. It has been shown that venous $\mathrm{ET}_{\mathrm{A}}$ receptor blockade inhibited ET-1 induced contraction to a larger degree when $\mathrm{ET}_{\mathrm{B}}$ receptors were blocked (Thakali et al. 2008). Crosstalk between $\mathrm{ET}_{\mathrm{A}}$ and $\mathrm{ET}_{\mathrm{B}}$ receptors has been shown to take place in several different blood vessels in rodents (Lodge et al. 1995, Thakali et al. 2008) and all of these vessels possess contractile $\mathrm{ET}_{\mathrm{A}}$ and $\mathrm{ET}_{\mathrm{B}}$ receptors and suggest that pharmacological $\mathrm{ET}_{\mathrm{A}}$ and $\mathrm{ET}_{\mathrm{B}}$ receptor interaction require the presence of contractile $\mathrm{ET}_{\mathrm{B}}$ receptors (Thakali et al. 2008). We have shown that $\mathrm{ET}_{\mathrm{A}}$ receptors modulate the cardiovascular responses of adrenergic agent such as clonidine (Gulati 1992, Gulati and Srimal 1993, Lavhale et al. 2013). Since centhaquin acts on adrenergic receptors it is possible that changes in expression of $\mathrm{ET}_{\mathrm{A}}$ receptors may be responsible for some of the resuscitative effects of centhaquin.

We found that in the renal medulla, $\mathrm{ET}_{\mathrm{A}}$ receptor levels were unaltered following hemorrhagic shock, but were decreased by centhaquin, whereas $\mathrm{ET}_{\mathrm{B}}$ receptor expression decreased following hemorrhagic shock, which was completely attenuated by centhaquin and not with hypertonic saline. In the kidney, ET-1 produces vasoconstriction and decreases glomerular filtration rate which is mediated through $\mathrm{ET}_{\mathrm{A}}$ receptors (Harris et al. 1991, Kon et al. 1989). A decrease in the expression of $\mathrm{ET}_{\mathrm{A}}$ receptors induced by centhaquin could reduce the vasoconstrictor effect of ET-1 in the renal medulla. The outer renal medulla is the site where extensive 
reabsorption of sodium chloride takes place by the thick ascending limb of loop of Henle making outer renal medulla a site for high metabolic activity and demand for better blood perfusion (Cowley 2008). Hence this region is highly prone to hypoxic or ischemic injury following excessive hemorrhage. It is possible that centhaquin by decreasing the concentration of $\mathrm{ET}_{\mathrm{A}}$ receptors may prevent the renal medullary region from ischemic injury following hemorrhagic shock. On the other hand, $\mathrm{ET}_{\mathrm{B}}$ receptor stimulation has been found to increase renal medullary blood flow mediated through vasodilators such as NO, cyclo-oxygenase and cytochrome p-450 metabolites (Hercule and Oyekan 2000, Vassileva et al. 2003). In the present study, hemorrhagic shock decreased renal medullary $\mathrm{ET}_{\mathrm{B}}$ receptor expression which was not affected by resuscitation with saline but was attenuated by centhaquin. Our results suggest that severe hemorrhage produces a decrease in the expression of $\mathrm{ET}_{\mathrm{B}}$ receptors in the renal medulla which may contribute towards a decrease in blood flow to the renal medulla causing ischemia and renal failure. Since resuscitation with centhaquin did not produce any decrease in renal medullary $\mathrm{ET}_{\mathrm{B}}$ receptor expression, it is possible that hemorrhage induced renal medullary ischemic effects could be attenuated by centhaquin. Therefore, centhaquin induced changes in $\mathrm{ET}_{\mathrm{A}}$ and $\mathrm{ET}_{\mathrm{B}}$ receptors both may be contributing to prevent the renal medulla from ischemic injury following hemorrhagic shock.

The renal medullary $\mathrm{ET}_{\mathrm{B}}$ receptors also play a role in the control of sodium and water excretion (Kohan et al. 2011, Schneider et al. 2007). $\mathrm{ET}_{\mathrm{B}}$ receptors in the epithelium of the renal medullary collecting ducts are mainly responsible for inhibition of ET-1 action on sodium and water reabsorption (Kitamura et al. 1989, Kohan et al. 2011). The diuretic and natriuretic response to ET-1 was found to be attenuated by an $\mathrm{ET}_{\mathrm{B}}$ receptor antagonist (Hoffman et al. 2000). Patients with excessive blood loss presenting with anuria or oliguria warrant emergency medical attention because acute kidney failure is the main cause of death in such patients (Rossaint et al. 2006). It is possible that a decrease in the expression of renal medullary $\mathrm{ET}_{\mathrm{B}}$ receptors may contribute towards oliguria which could be attenuated by centhaquin. It may be speculated that centhaquin could be a novel pharmacological intervention to reduce renal injury mediated by hemorrhagic shock. These findings are preliminary and only suggestive, they need to be extensively investigated in animal studies. Studies are needed to investigate the effect of centhaquin on renal blood flow and whether those changes can be antagonized by specific $\mathrm{ET}_{\mathrm{A}}$ and $\mathrm{ET}_{\mathrm{B}}$ receptor antagonists.

In the present study it was found that hemorrhage increased the plasma concentration of ET-1, TNF- $\alpha$, IL- 6 and IL-10. Resuscitation with hypertonic saline did not alter plasma ET-1, TNF- $\alpha$, IL-6 or IL-10; however, centhaquin significantly increased plasma ET-1, TNF- $\alpha$ and IL-6 without affecting plasma IL-10 concentration. In a study conducted in mongrel dogs an increase in plasma ET-1 levels was observed following hemorrhage which co-related with the amount of blood loss (Chang et al. 1993). ET-1 increases superoxide anion production and cytokine secretion (Kowalczyk et al. 2015, Virdis and Schiffrin 2003), along with activation of transcription factors such as NF- $\mathrm{kB}$ and expression of pro-inflammatory cytokines such as TNF- $\alpha$, IL-1, and IL-6. Cytokines, reciprocally, have been shown to modulate the secretion of ET-1 (Breuiller-Fouche et al. 2005, Yeager et al. 2012).

Hemorrhagic shock compromises the metabolic, cellular and inflammatory responses which can lead to multiple organ failure (Bonanno 2011, Gutierrez et al. 2004, Marik and Flemmer 2012). The response is typically characterized by release of pro-inflammatory cytokines such as IL- 6 or TNF- $\alpha$ appearing immediately following hemorrhagic shock (Mees et al. 2009). This is followed by a sustained release of anti-inflammatory cytokines such as IL-10 which may contribute towards immune depression (Oberholzer et al. 2000). The overall impact of excessive IL-6 and TNF- $\alpha$ production in hemorrhage is still controversial. The present findings confirm increases in plasma levels of TNF- $\alpha$, IL- 6 and IL-10 after hemorrhage. Resuscitation with hypertonic saline did not alter plasma TNF- $\alpha$, IL-6 or IL-10; however, centhaquin significantly increased plasma TNF- $\alpha$ and IL-6 without affecting plasma IL-10 concentration. Previous investigations have shown that an increased expression of $\mathrm{ET}_{\mathrm{B}}$ receptors may correlate with an increase in certain pro-inflammatory cytokines (Breuiller-Fouche et al. 2005, Pernow et al. 2000, White et al. 2000). We found that centhaquin resuscitation increased $\mathrm{ET}_{\mathrm{B}}$ receptor expression in the abdominal aorta and renal medulla along with elevating plasma TNF- $\alpha$ and IL-6 concentration. Studies have suggested that a robust early TNF- $\alpha$ response is associated with survival in trauma victims and early elevation of plasma TNF- $\alpha$ serves either to limit organ damage or to induce reparative processes (Namas et al. 2009). Cytokine IL-6 
seems to play a significant role in the systemic response to inflammation. Although several studies have shown beneficial effect of blockage of IL-6 in arthritis (Peake et al. 2006), multiple myeloma (Gado et al. 2000) and Crohn's disease (Atreya et al. 2000), inhibition of IL-6 has not been found to be beneficial in hemorrhagic shock (Mees et al. 2009). IL-6 plays a dual role in the inflammatory response to injury, often classified as proinflammatory locally and anti-inflammatory systemically. Studies have shown the beneficial effects of IL-6 deficiency in experimental paradigms of thermal injury, sepsis, and hemorrhage (Fontanilla et al. 2000, Mommsen et al. 2011, Yang et al. 2007). In contrast, other studies demonstrate that IL-6 administration prevents epithelial cell and cardio-myocyte apoptosis induced by hemorrhage (Alten et al. 2008, Moran et al. 2009). Systemic infusion of IL-6 following hemorrhagic shock reduces inflammation and injury in the liver and lung (Meng et al. 2000). Studies have also shown the beneficial effects of TNF- $\alpha$. Mice lacking TNF receptors have larger infarcts in ischemic brain injury (Bruce $e t$ al. 1996). TNF- $\alpha$ release in the hippocampus may promote neuroprotection and activate repair processes of the cerebral microvasculature as well as mediate neuronal plasticity (Kim et al. 2014, Sriram and O'Callaghan 2007). Several experimental studies suggest that both cytokines display protective actions in the brain (Bruce et al. 1996, Gadient et al. 1990, Hama et al. 1989, Kossmann et al. 1996). While centhaquin did increase IL- 6 and TNF- $\alpha$ in the present study, more markers for inflammation would need to be examined in order to fully understand the influence of centhaquin on inflammation, both in normal and hemorrhaged animals, as these cytokines have the capacity to perform both pro- and antiinflammatory functions.

The limitations of this study are the lack of mechanistic detail and causal relationships. Further studies are needed to confirm whether an increase in the expression of $\mathrm{ET}_{\mathrm{B}}$ receptors is responsible for an elevation in the concentration of plasma cytokines and how an increase in certain cytokines may contribute towards beneficial effect of centhaquin following hemorrhagic shock. In addition, studies using specific ET receptor antagonists are needed to confirm the involvement of ET receptors and it is possible that these finding are associative.

In summary, centhaquin significantly improves resuscitation following hemorrhagic shock in rats. The administration of centhaquin following HS resulted in a decrease in the expression of vasoconstrictor $\mathrm{ET}_{\mathrm{A}}$ receptor and an increase in the expression of vasodilator $\mathrm{ET}_{\mathrm{B}}$ receptors, the mechanism for these alterations remains to be determined. Similarly, the significance of elevation in cytokines following hemorrhagic shock and resuscitation with centhaquin is not known and needs to be investigated. It is speculated that these changes may improve tissue blood perfusion.

\section{Conflict of Interest}

Dr. Gulati has a pending patent and Dr. Lavhale is presently employed by Pharmazz, Inc. having rights to pending patent.

\section{Acknowledgements}

The authors would like to acknowledge the funding provided by Midwestern University.

\section{References}

ACOSTA JA, YANG JC, WINCHELL RJ, SIMONS RK, FORTLAGE DA, HOLLINGSWORTH-FRIDLUND P, HOYT DB: Lethal injuries and time to death in a level I trauma center. J Am Coll Surg 186: 528-533, 1998.

ALTEN JA, MORAN A, TSIMELZON AI, MASTRANGELO MA, HILSENBECK SG, POLI V, TWEARDY DJ: Prevention of hypovolemic circulatory collapse by IL-6 activated Stat3. PLoS One 3: e1605, 2008.

ARAI H, HORI S, ARAMORI I, OHKUBO H, NAKANISHI S: Cloning and expression of a cDNA encoding an endothelin receptor. Nature 348: 730-732, 1990.

ATREYA R, MUDTER J, FINOTTO S, MULLBERG J, JOSTOCK T, WIRTZ S, SCHUTZ M, BARTSCH B, HOLTMANN M, BECKER C, STRAND D, CZAJA J, SCHLAAK JF, LEHR HA, AUTSCHBACH F, SCHURMANN G, NISHIMOTO N, YOSHIZAKI K, ITO H, KISHIMOTO T, GALLE PR, ROSE-JOHN S, NEURATH MF: Blockade of interleukin 6 trans signaling suppresses T-cell resistance against apoptosis in chronic intestinal inflammation: evidence in Crohn disease and experimental colitis in vivo. Nat Med 6: 583-588, 2000.

BONANNO FG: Physiopathology of shock. J Emerg Trauma Shock 4: 222-232, 2011. 
BOURQUE SL, DAVIDGE ST, ADAMS MA: The interaction between endothelin-1 and nitric oxide in the vasculature: new perspectives. Am J Physiol Regul Integr Comp Physiol 300: R1288-R1295, 2011.

BREUILLER-FOUCHE M, MORINIERE C, DALLOT E, OGER S, REBOURCET R, CABROL D, LEROY MJ: Regulation of the endothelin/endothelin receptor system by interleukin-1\{beta\} in human myometrial cells. Endocrinology 146: 4878-4886, 2005.

BRIYAL S, NGUYEN C, LEONARD M, GULATI A: Stimulation of endothelin B receptors by IRL-1620 decreases the progression of Alzheimer's disease. Neuroscience 301: 1-11, 2015.

BRUCE AJ, BOLING W, KINDY MS, PESCHON J, KRAEMER PJ, CARPENTER MK, HOLTSBERG FW, MATTSON MP: Altered neuronal and microglial responses to excitotoxic and ischemic brain injury in mice lacking TNF receptors. Nat Med 2: 788-794, 1996.

BUEHLER PW, MEHENDALE S, WANG H, XIE J, MA L, TRIMBLE CE, HSIA CJ, GULATI A: Resuscitative effects of polynitroxylated alphaalpha-cross-linked hemoglobin following severe hemorrhage in the rat. Free Radic Biol Med 29: 764-774, 2000.

CARDILLO C, KILCOYNE CM, CANNON RO 3RD, PANZA JA: Interactions between nitric oxide and endothelin in the regulation of vascular tone of human resistance vessels in vivo. Hypertension 35: 1237-1241, 2000.

CHANG H, WU GJ, WANG SM, HUNG CR: Plasma endothelin level changes during hemorrhagic shock. J Trauma 35: 825-833, 1993.

CHAUDRY IH, AYALA A, ERTEL W, STEPHAN RN: Hemorrhage and resuscitation: immunological aspects. Am $J$ Physiol 259: R663-R678, 1990.

COWLEY AW JR: Renal medullary oxidative stress, pressure-natriuresis, and hypertension. Hypertension 52: 777-786, 2008.

DAVIS JW, KAUPS KL, PARKS SN: Base deficit is superior to $\mathrm{pH}$ in evaluating clearance of acidosis after traumatic shock. J Trauma 44: 114-118, 1998.

EDWARDS JD, DOVGAN PS, ROWLEY JM, AGRAWAL DK, THORPE PE, ADRIAN TE: Endothelin-1 levels in ischaemia, reperfusion, and haemorrhagic shock in the canine infrarenal aortic revascularisation model. Eur $J$ Vasc Surg 8: 729-734, 1994.

FONTANILLA CV, FAUNCE DE, GREGORY MS, MESSINGHAM KA, DURBIN EA, DUFFNER LA, KOVACS EJ: Anti-interleukin-6 antibody treatment restores cell-mediated immune function in mice with acute ethanol exposure before burn trauma. Alcohol Clin Exp Res 24: 1392-1399, 2000.

GADIENT RA, CRON KC, OTTEN U: Interleukin-1 beta and tumor necrosis factor-alpha synergistically stimulate nerve growth factor (NGF) release from cultured rat astrocytes. Neurosci Lett 117: 335-340, 1990.

GADO K, DOMJAN G, HEGYESI H, FALUS A: Role of interleukin-6 in the pathogenesis of multiple myeloma. Cell Biol Int 24: 195-209, 2000.

GARDINER SM, KEMP PA, MARCH JE, BENNETT T: Effects of bosentan (Ro 47-0203), an ETA-, ETB-receptor antagonist, on regional haemodynamic responses to endothelins in conscious rats. $\mathrm{Br} J$ Pharmacol 112: 823-830, 1994.

GOTO K, KASUYA Y, MATSUKI N, TAKUWA Y, KURIHARA H, ISHIKAWA T, KIMURA S, YANAGISAWA M, MASAKI T: Endothelin activates the dihydropyridine-sensitive, voltage-dependent $\mathrm{Ca} 2+$ channel in vascular smooth muscle. Proc Natl Acad Sci U S A 86: 3915-3918, 1989.

GULATI A: Evidence for antagonistic activity of endothelin for clonidine induced hypotension and bradycardia. Life Sci 50: 153-160, 1992.

GULATI A, SEN AP: Dose-dependent effect of diaspirin cross-linked hemoglobin on regional blood circulation of severely hemorrhaged rats. Shock 9: 65-73, 1998.

GULATI A, SRIMAL RC: Endothelin antagonizes the hypotension and potentiates the hypertension induced by clonidine. Eur J Pharmacol 230: 293-300, 1993.

GULATI A, SINGH R, CHUNG SM, SEN AP: Role of endothelin-converting enzyme in the systemic hemodynamics and regional circulatory effects of proendothelin-1 (1-38) and diaspirin cross-linked hemoglobin in rats. J Lab Clin Med 126: 559-570, 1995.

GULATI A, REBELLO S, KUMAR A: Role of sympathetic nervous system in cardiovascular effects of centrally administered endothelin-1 in rats. Am J Physiol 273: H1177-H1186, 1997a. 
GULATI A, SEN AP, SHARMA AC, SINGH G: Role of ET and NO in resuscitative effect of diaspirin cross-linked hemoglobin after hemorrhage in rat. Am J Physiol 273: H827-H836, $1997 \mathrm{~b}$.

GULATI A, LAVHALE MS, GARCIA DJ, HAVALAD S: Centhaquin improves resuscitative effect of hypertonic saline in hemorrhaged rats. $J$ Surg Res 178: 415-423, 2012.

GULATI A, ZHANG Z, MURPHY A, LAVHALE MS: Efficacy of centhaquin as a small volume resuscitative agent in severely hemorrhaged rats. Am J Emerg Med 31: 1315-1321, 2013.

GUTIERREZ G, REINES HD, WULF-GUTIERREZ ME: Clinical review: hemorrhagic shock. Crit Care 8: 373-381, 2004.

HAMA T, MIYAMOTO M, TSUKUI H, NISHIO C, HATANAKA H: Interleukin-6 as a neurotrophic factor for promoting the survival of cultured basal forebrain cholinergic neurons from postnatal rats. Neurosci Lett 104: 340-344, 1989.

HARRIS PJ, ZHUO J, MENDELSOHN FA, SKINNER SL: Haemodynamic and renal tubular effects of low doses of endothelin in anaesthetized rats. $J$ Physiol 433: 25-39, 1991.

HELMY A, JALAN R, NEWBY DE, JOHNSTON NR, HAYES PC, WEBB DJ: Altered peripheral vascular responses to exogenous and endogenous endothelin-1 in patients with well-compensated cirrhosis. Hepatology 33: 826-831, 2001.

HERCULE HC, OYEKAN AO: Cytochrome P450 omega/omega-1 hydroxylase-derived eicosanoids contribute to endothelin(A) and endothelin(B) receptor-mediated vasoconstriction to endothelin-1 in the rat preglomerular arteriole. J Pharmacol Exp Ther 292: 1153-1160, 2000.

HOFFMAN A, ABASSI ZA, BRODSKY S, RAMADAN R, WINAVER J: Mechanisms of big endothelin-1-induced diuresis and natriuresis: role of ET(B) receptors. Hypertension 35: 732-739, 2000.

JACOB M, KUMAR P: The challenge in management of hemorrhagic shock in trauma. Med J Armed Forces India 70: 163-169, 2014.

JOCHEM J, ZWIRSKA-KORCZALA K, GWOZDZ B, WALICHIEWICZ P, JOSKO J: Cardiac and regional haemodynamic effects of endothelin-1 in rats subjected to critical haemorrhagic hypotension. $J$ Physiol Pharmacol 54: 383-396, 2003.

KIM JY, KAWABORI M, YENARI MA: Innate inflammatory responses in stroke: mechanisms and potential therapeutic targets. Curr Med Chem 21: 2076-2097, 2014.

KITAMURA K, TANAKA T, KATO J, OGAWA T, ETO T, TANAKA K: Immunoreactive endothelin in rat kidney inner medulla: marked decrease in spontaneously hypertensive rats. Biochem Biophys Res Commun 162: 38-44, 1989.

KOHAN DE, ROSSI NF, INSCHO EW, POLLOCK DM: Regulation of blood pressure and salt homeostasis by endothelin. Physiol Rev 91: 1-77, 2011.

KON V, YOSHIOKA T, FOGO A, ICHIKAWA I: Glomerular actions of endothelin in vivo. $J$ Clin Invest 83: 1762$1767,1989$.

KOSSMANN T, HANS V, IMHOF HG, TRENTZ O, MORGANTI-KOSSMANN MC: Interleukin-6 released in human cerebrospinal fluid following traumatic brain injury may trigger nerve growth factor production in astrocytes. Brain Res 713: 143-152, 1996.

KOWALCZYK A, KLENIEWSKA P, KOLODZIEJCZYK M, SKIBSKA B, GORACA A: The role of endothelin-1 and endothelin receptor antagonists in inflammatory response and sepsis. Arch Immunol Ther Exp 63: 41-52, 2015.

LAVHALE MS, BRIYAL S, PARIKH N, GULATI A: Endothelin modulates the cardiovascular effects of clonidine in the rat. Pharmacol Res 62: 489-499, 2010.

LAVHALE MS, HAVALAD S, GULATI A: Resuscitative effect of centhaquin after hemorrhagic shock in rats. $J$ Surg Res 179: 115-124, 2013.

LEONARD MG, GULATI A: Endothelin B receptor agonist, IRL-1620, enhances angiogenesis and neurogenesis following cerebral ischemia in rats. Brain Res 1528: 28-41, 2013.

LODGE NJ, ZHANG R, HALAKA NN, MORELAND S: Functional role of endothelin ETA and ETB receptors in venous and arterial smooth muscle. Eur J Pharmacol 287: 279-285, 1995. 
LOWRY OH, ROSEBROUGH NJ, FARR AL, RANDALL RJ: Protein measurement with the Folin phenol reagent. J Biol Chem 193: 265-275, 1951.

MAGGI CA, MELI A: Suitability of urethane anesthesia for physiopharmacological investigations in various systems. Part 2: Cardiovascular system. Experientia 42: 292-297, 1986.

MARIK PE, FLEMMER M: The immune response to surgery and trauma: implications for treatment. $J$ Trauma Acute Care Surg 73: 801-808, 2012.

MEES ST, TOELLNER S, MARX K, FAENDRICH F, KALLEN KJ, SCHROEDER J, HAIER J, KAHLKE V: Inhibition of interleukin-6-transsignaling via gp130-Fc in hemorrhagic shock and sepsis. J Surg Res 157: 235-242, 2009.

MENG ZH, DYER K, BILLIAR TR, TWEARDY DJ: Distinct effects of systemic infusion of G-CSF vs. IL-6 on lung and liver inflammation and injury in hemorrhagic shock. Shock 14: 41-48, 2000.

MICKLEY EJ, GRAY GA, WEBB DJ: Activation of endothelin ETA receptors masks the constrictor role of endothelin ETB receptors in rat isolated small mesenteric arteries. Br J Pharmacol 120: 1376-1382, 1997.

MOMMSEN P, BARKHAUSEN T, FRINK M, ZECKEY C, PROBST C, KRETTEK C, HILDEBRAND F: Productive capacity of alveolar macrophages and pulmonary organ damage after femoral fracture and hemorrhage in IL-6 knockout mice. Cytokine 53: 60-65, 2011.

MORAN A, TSIMELZON AI, MASTRANGELO MA, WU Y, YU B, HILSENBECK SG, POLI V, TWEARDY DJ: Prevention of trauma/hemorrhagic shock-induced lung apoptosis by IL-6-mediated activation of Stat3. Clin Transl Sci 2: 41-49, 2009.

NAMAS R, GHUMA A, TORRES A, POLANCO P, GOMEZ H, BARCLAY D, GORDON L, ZENKER S, KIM HK, HERMUS L, ZAMORA R, ROSENGART MR, CLERMONT G, PEITZMAN A, BILLIAR TR, OCHOA J, PINSKY MR, PUYANA JC, VODOVOTZ Y: An adequately robust early TNF-alpha response is a hallmark of survival following trauma/hemorrhage. PLoS One 4: e8406, 2009.

OBERHOLZER A, OBERHOLZER C, MOLDAWER LL: Cytokine signaling - regulation of the immune response in normal and critically ill states. Crit Care Med 28: N3-N12, 2000.

PACHER P, NAGAYAMA T, MUKHOPADHYAY P, BATKAI S, KASS DA: Measurement of cardiac function using pressure-volume conductance catheter technique in mice and rats. Nat Protoc 3: 1422-1434, 2008.

PALADINO L, SINERT R, WALLACE D, ANDERSON T, YADAV K, ZEHTABCHI S: The utility of base deficit and arterial lactate in differentiating major from minor injury in trauma patients with normal vital signs. Resuscitation 77: 363-368, 2008.

PAPAPANAGIOTOU P, XANTHOS T, GULATI A, CHALKIAS A, PAPALOIS A, KONTOULI Z, ALEGAKIS A, IACOVIDOU N: Centhaquin improves survival in a swine model of hemorrhagic shock. $J$ Surg Res 200: 227-235, 2016.

PEAKE NJ, KHAWAJA K, MYERS A, NOWELL MA, JONES SA, ROWAN AD, CAWSTON TE, FOSTER HE: Interleukin-6 signalling in juvenile idiopathic arthritis is limited by proteolytically cleaved soluble interleukin6 receptor. Rheumatology 45: 1485-1489, 2006.

PERNOW J, BOHM F, JOHANSSON BL, HEDIN U, RYDEN L: Enhanced vasoconstrictor response to endothelin-Breceptor stimulation in patients with atherosclerosis. J Cardiovasc Pharmacol 36: S418-S420, 2000.

ROSSAINT R, CERNY V, COATS TJ, DURANTEAU J, FERNANDEZ-MONDEJAR E, GORDINI G, STAHEL PF, HUNT BJ, NEUGEBAUER E, SPAHN DR: Key issues in advanced bleeding care in trauma. Shock 26: 322-331, 2006.

SANCHEZ A, CONTRERAS C, MARTINEZ P, MUNOZ M, MARTINEZ AC, GARCIA-SACRISTAN A, HERNANDEZ M, PRIETO D: Endothelin A (ET(A)) receptors are involved in augmented adrenergic vasoconstriction and blunted nitric oxide-mediated relaxation of penile arteries from insulin-resistant obese zucker rats. $J$ Sex Med 11: 1463-1474, 2014.

SANDOO A, VAN ZANTEN JJ, METSIOS GS, CARROLL D, KITAS GD: The endothelium and its role in regulating vascular tone. Open Cardiovasc Med J 4: 302-312, 2010.

SCHNEIDER MP, BOESEN EI, POLLOCK DM: Contrasting actions of endothelin ET(A) and ET(B) receptors in cardiovascular disease. Annu Rev Pharmacol Toxicol 47: 731-759, 2007. 
SHACKFORD SR, MACKERSIE RC, HOLBROOK TL, DAVIS JW, HOLLINGSWORTH-FRIDLUND P, HOYT DB, WOLF PL: The epidemiology of traumatic death. A population-based analysis. Arch Surg 128: 571-575, 1993.

SHARMA AC, SINGH G, GULATI A: Decompensation characterized by decreased perfusion of the heart and brain during hemorrhagic shock: role of endothelin-1. J Trauma 53: 531-536, 2002.

SRIRAM K, O'CALLAGHAN JP: Divergent roles for tumor necrosis factor-alpha in the brain. $J$ Neuroimmune Pharmacol 2: 140-153, 2007.

THAKALI K, GALLIGAN JJ, FINK GD, GARIEPY CE, WATTS SW: Pharmacological endothelin receptor interaction does not occur in veins from ET(B) receptor deficient rats. Vascul Pharmacol 49: 6-13, 2008.

VASSILEVA I, MOUNTAIN C, POLLOCK DM: Functional role of ETB receptors in the renal medulla. Hypertension 41: 1359-1363, 2003.

VIRDIS A, SCHIFFRIN EL: Vascular inflammation: a role in vascular disease in hypertension? Curr Opin Nephrol Hypertens 12: 181-187, 2003.

WHITE LR, JUUL R, SKAANES KO, AASLY J: Cytokine enhancement of endothelin ET(B) receptor-mediated contraction in human temporal artery. Eur J Pharmacol 406: 117-122, 2000.

WU D, DAI H, ARIAS J, LATTA L, ABRAHAM WM: Low-volume resuscitation from traumatic hemorrhagic shock with $\mathrm{Na}+/ \mathrm{H}+$ exchanger inhibitor. Crit Care Med 37: 1994-1999, 2009.

YANAGISAWA M, KURIHARA H, KIMURA S, TOMOBE Y, KOBAYASHI M, MITSUI Y, YAZAKI Y, GOTO K, MASAKI T: A novel potent vasoconstrictor peptide produced by vascular endothelial cells. Nature 332: 411-415, 1988.

YANG S, HU S, CHOUDHRY MA, RUE LW 3RD, BLAND KI, CHAUDRY IH: Anti-rat soluble IL-6 receptor antibody down-regulates cardiac IL-6 and improves cardiac function following trauma-hemorrhage. $\mathrm{J} \mathrm{Mol} \mathrm{Cell}$ Cardiol 42: 620-630, 2007.

YEAGER ME, BELCHENKO DD, NGUYEN CM, COLVIN KL, IVY DD, STENMARK KR: Endothelin-1, the unfolded protein response, and persistent inflammation: role of pulmonary artery smooth muscle cells. $\mathrm{Am} J$ Respire Cell Mol Biol 46: 14-22, 2012. 